Insignia Journal of International Relations

Vol. 7, No.1, April 2020, 17-44

P-ISSN: 2089-1962; E-ISSN: 2597-9868

\title{
U.S. Foreign Policy Towards Iranian Nuclear Threat from Bill Clinton to Donald Trump Administration
}

\author{
Anak Agung Banyu Perwita \\ Program Studi Hubungan Internasional, President University \\ Email: aabanyu.perwita@gmail.com \\ Muhammad Ilham Razak \\ Program Studi Hubungan Internasional, President University \\ Email: ewakoilham@gmail.com
}

\begin{abstract}
Iranian nuclear threat remains one of the most pressing issue throughout the history of US foreign policy. Ever since the Islamic revolution occured in Iran in 1979, Iran hostile activities in Middle East has been a major threat for US security interest, in particular when Iran started to build its ambition to build its nuclear weapon. Having said that, this article aims to discuss US foreign policy toward the threat of Iranian nuclear program from Bill Clinton administration until Trump Administration. By using qualitative method specifically on thematic analysis from Braun and Clarke, this article would scrutinize the internal and external factors of US foreign policy toward Iran and then seeks to understand the change and continuity of US foreign policy from Bill Clinton until Trump administration. From the analysis, it was found that US foreign policy has been influenced a lot by its internal and external factors, resulting in different responses of US foreign policy in each administration. Moreover, US foreign policy has been consistent to put Iranian nuclear threat as its major security threat despite differ in its foreign policy. However, the withdrawal of US under Trump in Joint Comprehensive Plan Of Action (JCPOA) deal has provided an inconsistency of US foreign policy with its previous administration.
\end{abstract}

Keywords: change and continuity, internal and external factors, Iranian nuclear threat, US foreign policy

\begin{abstract}
Abstrak
Ancaman nuklir Iran tetap menjadi salah satu isu yang paling mendesak dalam sejarah kebijakan luar negeri Amerika Serikat. Sejak revolusi islam terjadi di tahun 1979, aktivitas berbahaya Iran di Timur Tengah telah menjadi ancaman besar bagi kepentingan keamanan US, terutama saat Iran mulai membangun ambisinya untuk membuat senjata nuklir. Oleh karena itu, artikel ini bertujuan untuk mendiskusikan kebijakan luar negeri Amerika Serikat terhadap ancaman nuklir Iran mulai dari kepemimpinan Bill Clinton sampai kepemimpinan Donald Trump. Dengan menggunakan metode kualitatif spesifiknya pada analisis tematik dari Braun dan Clarke, artikel ini akan meneliti secara mendalam faktor-faktor internal dan external kebijakan luar negeri Amerika Serikat terhadap Iran dan kemudian memahami perubahan-perubahan dan kontinuitas kebijakan Amerika Serikat dari kepemimpinan Bill Clinton sampai kepemimpinan Donald Trump. Dari analisa artikel ini, ditermukan bahwa kebijakan luar negeri Amerika Serikat banyak banyak dipengaruhi oleh faktor-faktor internal dan external Amerika Serikat, sehingga menghasilkan respon yang berbeda-beda di setiap periode. Lebih jauh lagi, kebijakan luar negeri Amerika Serikat telah konsisten dalam menempatkan ancaman nuklir Iran sebagai ancaman besar terhadap kepentingan keamanan Amerika Serikat meskipun memiliki perbedaaan dalam menjalankan kebijakannya. Namun, mundurnya Amerika Serikat di perjanjian Joint Comprehensive Plan of Action (JCPOA) telah membuat adanya inkonsistensi pada kebijakan luar negeri Amerika dalam kepemimpinan yang sebelumnya.
\end{abstract}

Kata kunci: ancaman nuklir Iran, faktor internal dan eksternal, kebijakan luar negeri Amerika Serikat, perubahan dan kontinuitas 


\section{INTRODUCTION}

In the world where anarchical system and unequal distribution of power exists, the ultimate aim of states is to attain security (Waltz, 1979). As the consequences, states will seek to maximize its security by gaining more power and will respond to any threats that could jeopardize its security. Particularly for global powers, achieving security requires them to aspire to be a global hegemonic and will take necessary actions in responding to any states that reject their hegemony (Marsheimer J. J., 2001).

Deemed as the major power over the last century, United States has been actively engaging in many parts of the world to maintain its global hegemony (Pass, 2019). Especially after the Cold War era-as written in its national defense strategy year 1994-U.S. planned to remain globally engaged in shaping the international security environment (Department of Defense United States of America, 1994). These strategic objectives have been consistent if we look upon security strategies over the last decades up until now.

One of the US biggest agenda in shaping the global security environment lies on deterrence on proliferation of weapons of mass destruction. In fact, United States is in the forefront of asserting this objective. Jonathan Hunt (2017) on his works "Nuclear Arms Control in U.S. Foreign Policy" stated that US particularly started to center its attention toward the nuclear proliferation after the Soviet Union collapsed in 1991 in which also where the regional disputes, non-state actors, and failed states grew even more prominent." As I observed in US national security strategy since 1993 until the latest one in 2017, US foreign policy objective has been consistently put great interest to limit, reduce, and prevent the spread of, or eliminating weapons of mass destruction and other dangerous weapon in other states across the regions (Department of Defense United States of America, 2017).

Among all issues faced by United States on weapons of mass destruction, the most pressing one lies at Iran nuclear development program (White House, 2017). Robert Einhorn (2019), believed that the effort to prevent Iran from acquiring nuclear weapons has been the US national security priority for over three decades. The hostile relationship between US and Iran also contributed to this issue. As their diplomatic relation broke off in 1979 following the Iranian Revolution, Iran since then saw US as the "Great Satan who shouted and gathered all devils that has started a ruckus against Iran" (Iran Data Portal, 1979). In the speech of Ayatollah Khomeini on November 1979, the supreme leader confidently stated that "We must go forward with power. If we show weakness, they will be emboldened and will attack." (Iran Data Portal, 1979). Since then, Iran started to advance its nuclear weapon particularly when the state built its P-1 centrifuge in 1989 (Arms Control Association, 2019).

In response to the hostile behavior of Iran, United States has intensely engaged in series of efforts to stop Iran nuclear program (Robert Einhorn, 2019). From Bill Clinton administration until Donald Trump administration, each of the president has employed a series of foreign policy that are intended to stop Iran's nuclear weapon ambition, ranging from economic sanctions, international pressure, diplomatic solution, even military intervention. These were all available as an option in curbing Iranian nuclear weapon program.

The discourse on US foreign policy towards Iran is abundant in the current literature of international relations study. However, the US foreign policy study that specifically discussing on individual level in considering their states domestic and external environment in a comprehensive manner remains understudied. As echoed by Rosati (1995), despite the value of 
individual level analysis should be obvious; the study on this level has not always received the attention it deserves in the study of foreign policy. However, individual level of analysis has played a more prominent role in foreign policy research in the last decades, considering its strength to analyze the micro-level of decision making process within a state (Rosati, 1995). Not to mention that there is not much literature on US foreign policy study that specifically talking about Iranian nuclear threat in each administration in historical perspective.

Therefore, this article aims to analyze the US foreign policy towards Iranian nuclear threat from Bill Clinton until Donald Trump administration. Firstly, this article will begin by exploring US strategic environment encompassing its internal (domestic) and external (international) environment from Bill Clinton until Donald Trump administration. Secondly, this article analyzes the employment of U.S. foreign policy towards Iran from Bill Clinton administration until Trump administration. From this section, the writers scrutinize the change and continuity of each administration and understand the differences of each administration.

\section{Literature Review}

Terry Deibel (2007) posits that successful strategy in the foreign policy does not only end in the real world of international relations, but it also begins from that reality. Therefore, the success of foreign policy is determined by whether or not the outcome can influence the changing of the reality of international strategic environment according to the states' interest. In order to do so, as Deibel argued, state must begin by drawing accurate mental picture of its domestic and international reality (Deibel, 2007). This is important since according to Hill (2003), "foreign policy is the hinge of domestic and international politics." Put it in other words, foreign policy serves as an intersection point of domestic and international politics which later will contribute on how states will employ its foreign policy (Hill, The Changing Politics of Foreign Policy, 2003). From this point of view, we can understand that foreign policy was heavily influenced by states internal environment and its external environment. The combination of these factors would later contribute to the employment of states foreign policy.

However, as many of the current literature suggested, the domestic consideration on US foreign policy in particular to Iranian nuclear weapon is still understudied. As Homan \& Lantis pointed out that domestic politics such as political parties in US Congress representing the most interesting discussion on how it could challenge the authority, encouraging innovative ideas, and changing the foreign policy environment, yet, they are still lacking of presence in the US foreign policy study (Hoffman \& Lantis, 2019). This particular study will benefit from the exclusivity of understanding the domestic politics of US in shaping its foreign policy. Interestingly, it is not only encompassing the political parties interaction but also coming from other essential element in the internal politics of US that specifically significant to the US foreign policy towards Iran such as the concern of interest groups. This argument is validated by Helen Milner \& Dustin Tingley (2015) in which they found that there are two things that significantly trigger U.S. Presidents to formulate their foreign policy, they are domestic politics and the concern of interest group.

Moreover, the US strategic external consideration that specifically discussing on Iranian nuclear weapon has also being understudied. As Moritz Pieper argued, despite becoming fundamental to understand US foreign policy, the understudied of states' external considerations in seeing Iran as a threat remains to be vital point to understand Iran foreign policy in pursuing its nuclear weapon (Pieper, 2017). The discourse on 
the literature of external environment is important in order to understand the bigger picture of how states interact to specific issue. Unlike other studies that usually focus on the relation between US-Iranian relations to understand Iranian nuclear ambition. There is an urgency for th e writer to discuss other external environment that contribute to the US action to stop Iranian nuclear weapons aside from merely its relation with Iran.

Moreover, it is argued that external environment is the very reason why foreign policy was employed (Bojang, 2018). External environment here is defined as the reality perceived by states on the international system, in which, trigger states to act and respond to the situation in order to survive (Ripsman, Taliaferro, \& Lobell, Neoclassical Realist Theory of International Politics, 2016). Many international scholars often assess the international system as the starting point in understanding how states act in its foreign policy (Ripsman, Taliaferro, \& Lobell, Neoclassical Realist Theory of International Politics, 2016).

As pointed out by Gideon Rose (1998) in his article Neoclassical Realism and Theories of Foreign Policy, it is stated that "the scope and ambition of a country's foreign policy is driven first and foremost by its place in the international system and specifically by its relative material power capabilities". Put it in other words, in order to be able to understand the states foreign policy, it is imperative to understand first how states positioned itself in the international system and how its external environment creating stimulus for states to act and respond to it. Based on U.S. National Security Strategy in 1994-2017, there are two most important external environments that U.S. often consider in regard to Iranian nuclear threat. First is the international pressure on Iran and second is the U.S. commitment to protect Israel in the Middle East.

Having said that, we can understand that U.S. foreign policy on Iran is influenced by its domestic and international factors. For domestic factors, it encompasses domestic politics and interest group whereas external factors encompass international pressure on Iran and U.S. commitment to protection Israel in the Middle East. For simplicity, the literature review on U.S. foreign policy toward Iranian nuclear threat can be visualized by the figure below: 


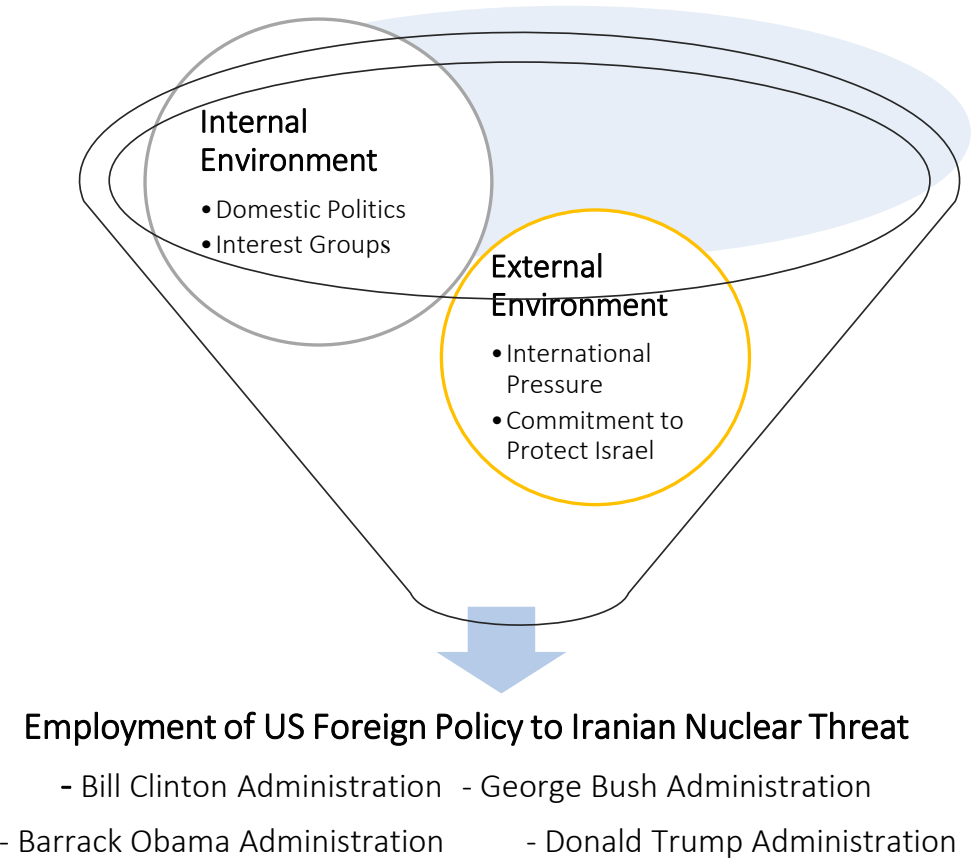

Source: Visualization of Strategic Environment Consideration in States' Decision Making Process made by the authors.

Figure 1

Internal and External US Strategic Environment that Contributed to US

Foreign Policy toward Iran

\section{Research Methods}

In order to gain a comprehensive insight about the change and continuity of U.S. foreign policy towards Iran throughout the history, this article uses the qualitative research by describing, interpreting, and contextualizing U.S. foreign policy on each administration. The method to gather data for this research will be relying on primary data which can be obtained from government official documents, books, academic journals, and the reliable official news website. In analyzing the data, the writer uses thematic analysis, which is used to analyze data in order to identify the ideas and patterns of meaning in the data (Braun \& Clarke, 2006). According to Braun \& Clarke (2006) this method is an effective tool to make the linkage between patterns in certain phenomena and understand how far the phenomenon happens in the writer's perspective.

\section{RESULT AND DISCUSSION}

In this section, the writer divides the analysis based on the three subsections. Firstly, the writer discusses U.S. internal environment in regard to Iranian nuclear threat. Secondly, the writer discusses U.S. external environment in regard to Iranian nuclear threat. Last but not least, the change and continuity on U.S. Foreign Policy from Bill Clinton administration until Donald Trump administration.

\section{Internal Environment}

The Constraints of Domestic Politics

Republican and Democrats-the leading political parties both in public and congress - play a significant contribution when it comes to the constraint of U.S. domestic politics. As both of these parties typically are divided by ideologies such as liberals and conservatives, Democrats and Republicans have been disagreed on many 
aspects of foreign policy. They disagree on which countries can be trusted and they feel close to, disagree on which foreign policy instruments and policies are best to employ, disagree on utility of foreign aids, benefits of trade and usefulness of diplomacy, or whether to use international organization and multilateral agreement in general (Milner \& Tingley, 2015).

In particular to Iran nuclear threat, both of political parties has been long known to have different view on how U.S. should employ its foreign policy. When Bill Clinton administration initiated a dual containment policy against Iran, Clinton asserted that U.S. focus is to change Iran behavior due to its quest for nuclear weapons (Brzezinski, 1997). However this objective began to harden as soon as Republican Party dominated the congress in 1994. Under the pressure of congressional republicans, Bill Clinton then signed the Iran Sanctions Act which mandated sanctions against any foreign firm in energy sector that invest more than $\$ 40$ million to Iran (Brzezinski, 1997). In addition, there was also an intention of Bill Clinton himself to normalize the relationship with Iran through Khatami, a newly elected moderate President in 1996. However, this intention was so unpopular in the congress, believing that Khatami could not control the radicals in Iran and believed that Khatami was pretending to be moderate to put Iran's enemies off guard while trying to acquire nuclear weapon (Freedman, 1999). As the consequences, throughout his presidency, Bill Clinton did not really fully employ his policy he imagined because of the constraint in domestic politics.

The constraint of domestic politics also happened during George Bush era. At this time, the constraint was coming from Democratic Party. During this period, under Bush leadership, the U.S. had considered to strike a military attack against Iran or so called as the pre-emptive attack. Under U.S. National Security Strategies 2006, it was stated that "We may face no greater challenge from a single country than from Iran ... if necessary, under long-standing principles of self defense, we do not rule out the use of force before attacks occur" (The White House, 2006, p. 20) This was also reinforced by the U.S. National Strategy President Directive entitled "National Strategy to Combat Weapon of Mass Destruction (WMD)" stated that "U.S. military forces and domestic law enforcement agencies as appropriate must stand ready to respond against the source of any WMD attack ...including in appropriate cases through preemptive measures" (Bush, 2002, p. 3) Dick Cheney, a former vice president at that time even insisted that military solution is not just a viable option, but the best option available (Borger, Cheney pushes Bush to Act on Iran, 2007).

However, this policy option was heavily pressured by the congress particularly on Democrat party, believing that military strike against Iran would only worsen the objective and too costly for U.S. (Plesch \& Buthcer, 2007). Joe Biden, a senator of democrat at that time even threatens the President to be impeached if the Bush Administration pursued this kind of policy (Memoli, 2019). Lack of domestic support to strike a military force against Iran had left Bush no choice but to fully engage Iran in diplomatic way along with economic sanctions. In fact, under the pressure of congress, Bush signed a bill that sanctioned oil and gas companies who involved doing business with Iran (Plesch \& Buthcer, 2007).

Meanwhile under Obama leadership, the republican-led congress also had shown a big challenge for Obama in pursuing his policy towards Iran. Obama pursued to engage in a more constructive and diplomatic manner to Iran by initiating the JCPOA deal, in which a deal that would restrict limited Iran's nuclear development in return for the lifting economic sanctions (Obama, 2016). However, the deal as what Obama imagined to be a treaty was not fully envisioned since majority of the congress 
opposed the deal. Hence, the deal was not becoming a treaty nor an executive agreement, but rather a political commitment from U.S. (Marcos, 2015). However, despite of the internal dispute in U.S., the international community such as UN and other P-5 countries use this as the foundation to make an international deal which strengthened through UNSC resolution in 2015 (UNSC, 2015).

When Donald Trump administration took into place, the president also did not run the foreign policy smoothly without constraints. When Donald Trump promised in his campaigned that he will withdraw from JCPOA deal, the reaction from U.S. domestic were filled with major disagreement. According to the poll conducted by SSRS, $63 \%$ of Americans or almost two-thirds of them believed that U.S. should not withdraw from the JCOPA deal (SSRS, 2017). Not only from public, internal administration of the current government such as National Security Adviser H.R. McMsster, Secretary of Defense James Mattis, and even Secretary of State Rex Tillerson also in support to maintain the deal (Crowley, 2017).

The pressure also was coming from Donald Trump's political party, Republican. Moreover, according to the poll, $48 \%$ of the republicans are supporting U.S. to remain to the deal (SSRS, 2017). In fact, Republican chairman of the U.S. House of Representatives Foreign Affairs committee Ed. Royce stated firmly that the deal should be strictly enforced by U.S. rather than abandon it (Gould \& III, 2017). Moreover, a group filled with both republican and democrats affiliated of more than 100 U.S. national security experts and more than 30 former U.S. ambassadors issued a joint statement urging Trump to remain in the Iran Nuclear deal (Cohen, 2018) .

Based on the four administrations above, we can clearly see how both of parties have significant differences on how U.S. should deal with Iranian nuclear threat. In Republican side, they pursue more on an aggressive stance towards Iran nuclear threat which included but not limited to regime changes, maximum pressure, and even military strike. However in Democratic perspective, they believe more on the diplomatic approach and multilateral agreement by believing that pressure can only be effective through multilateral approach and diplomatic manner. In order to make it easier to understand, we provide the matrix below to understand the challenges from each U.S. Presidents in facing the congress particularly the Republican and Democrat party in the process of foreign policy making towards Iran nuclear threat:

Table 1

The Summary of the Constraints of Domestic Politics within Congress in US Foreign Policy

\begin{tabular}{|c|l|l|}
\hline Administration & \multicolumn{1}{|c|}{ Republican Party } & \multicolumn{1}{c|}{ Democrat Party } \\
\hline Bill Clinton & $\begin{array}{l}\text { Pressure to take a harder } \\
\text { economic sanctions toward Iran }\end{array}$ & $\begin{array}{l}\text { Support Clinton for } \\
\text { engagement with Khatami }\end{array}$ \\
\hline George Bush & $\begin{array}{l}\text { Pressure Bush to pursue a } \\
\text { regime change for Iran }\end{array}$ & $\begin{array}{l}\text { Discourage Bush to take } \\
\text { military action toward Iran }\end{array}$ \\
\hline Barrack Obama & $\begin{array}{l}\text { Oppose the JCPOA deal. } \\
\text { Cancelling the JCPOA deal to be } \\
\text { a treaty. }\end{array}$ & $\begin{array}{l}\text { Support the JCPOA deal and } \\
\text { support the deal to be a treaty }\end{array}$ \\
\hline Donald Trump & $\begin{array}{l}52 \% \text { Support the withdrawal. } \\
48 \% \text { want to remain in the deal }\end{array}$ & Oppose the withdrawal \\
\hline
\end{tabular}

Sources: All these statements were quoted from various sources explained in the previous explanations. See bibliography. 
The Concern of Domestic Interest Groups

In particular to Iran nuclear threat, domestic groups have been contributed a lot to consideration of US decision makers. Amongst all interest groups that reside in U.S., the domestic interest groups that significantly contribute to the U.S. foreign policy is American Israel Public Affairs Committee (AIPAC). AIPAC has been working more than 20 years to lobby the U.S. executive branch and the U.S. congress. According to AIPAC itself, its primary goal is to work with the U.S. government to strengthen U.S.-Israel relationship and pursue economic, political and diplomatic measures to prevent a nuclear-armed Iran. It is claimed itself by AIPAC, that the AIPAC organization highly encourage the construction of a tough broad sanctions towards Iran to prevent them for acquiring nuclear weapon (AIPAC, 2019).

As for example, during Clinton Administration, AIPAC drafted and circulated 74-pages paper in Washington arguing that Iran was not only a threat to Israel, but also for the U.S. and its allies (Pollack K. M., 2004). In its paper conclusion, AIPAC suggested U.S. to put higher economic sanctions towards Iran. This influence of course contributed to the Iran Libya Sanctions Act 1996 particularly when AIPAC was given privileged to revise the bill in prior (Marsheimers \& Waltz, The Israel Lobby and US Foreign Policy, 2007). When the newly elected moderate Iranian President Khatami was in charge, there was an intention for both U.S. and Iran to improve its relations. However, AIPAC stepped up to act intensively in Congress to prevent this approach (Yerah, 1997).

During George Bush administration, AIPAC tried to convince the government about strategic environment in the Middle East, believing that U.S. targets should be focusing on Israel's foes to apply maximum pressures on Iran and even should change the regime. Moreover, according to Marsheimers \& Waltz (2007), the lobby groups played a critical role in shaping U.S. policy towards Iran to transform to be democratic country.

On May 2003, the congress planned to introduce a bill to fund opposition groups and promote democracy in Iran, which backed by AIPA, Coalition for Democracy in Iran, and Jewish Institute for National Security of America (JINSA). Later on July, the bill was passed by congress and Bill Clinton signed the legislation. In addition, Marsheimers \& Waltz argued that these domestic Israel groups have been successfully convincing Bush that "Iran is unacceptable threat to Israel and that it is the responsibility of the U.S. to prevent the threat from increasing." It was not even rare to see such as AIPAC in their publication and lobby to the American politician leaders to support the argument of U.S. executives to employ military strike towards Iran in the hope for Iranian regime change (Shuel, 2006) (Guttman, 2007).

When Obama stepped up as the President and began to initiate the JCPOA deal, the domestic interest groups were increasingly becoming more active than before (Shank, 2015). It was reported that the American Israel Public Affairs Committee (AIPAC) spent about \$1.67 millions in to lobby the Congress to enact legislation giving senators the ability to review an Iran nuclear deal (Ho, 2015). AIPAC also spent $\$ 20$ million dollars to form a group so-called as Citizens for a Nuclear Free Iran to educate the public about the dangers of the Iran deal (Davis, 2017). However, AIPAC was not alone, the other interest group such as New Security Action and J Streets also made an effort to do counter narrative the effort of AIPAC to the support the deal to the public (Toosi, 2016).

In particular for Donald Trump administration, the intention to withdraw from JCPOA deal surely triggers many interest groups to participate to the U.S. potential foreign policy outcome. At this time, Jewish groups are divided into two 
factions; those who support Trump to withdraw from the deal such as AIPAC and Orthodox Union, and those who oppose Trumps' deal such as J Street and the Jewish Democratic Council of America (Tibon, 2018). Both of these factions have demonstrated their activities in lobbying many stakeholders in U.S. government to persuade them to choose the policy they prefer, mainly through congress, public campaign, and of course to Trump himself (Tibon, 2018). The executives of Republican Jewish Coalition even set the meeting with Donald Trump to encourage Trump to withdraw the deal for the best interest of U.S. and its allies. In fact, it was reported that Jewish groups and donors spent more than $\$ 22 \mathrm{my}$ on lobbying and campaign to encourage Trump to withdraw the deal in 2018 (Perkins, 2019).

Based on the explanation above, we can understand that domestic interest groups have proven to contribute to the U.S. foreign policy making. Particularly for the leader as the pinnacle of decision maker, domestic group cannot be denied their existence and contribution to shape the reality and contextualize the potential response of U.S. foreign policy towards Iran. of course, there is no exact point to what extend does domestic interest group can influence leaders' decision. But what we can understand from this point is that domestic interest groups can be either a constraint or a support that leaders can use to execute their foreign policy.

\section{External Environment}

\section{International Pressure on Iran over Nuclear} Threat

Iran nuclear development has been long known to be suspicious in the eyes of international community (Karakir, 2008). Despite yet to be officially armed with nuclear weapons, Iran nuclear activities has been a huge concern for not only U.S. but also for Gulf countries in the Middle East, European Union and United Nations (The White House, 2002).
The engagement with international community has always been a reliable tool for U.S. strategic decision in handling Iran nuclear threat since Bill Clinton administration. As for example, Bill Clinton believed that "U.S. leadership has been crucial to the success of negotiations that produced a wide range of treaties that have made the world safer and more secure by limiting, reducing, preventing the spread of, or eliminating weapons of mass destruction (WMD) and other dangerous weapons. Without our leadership and engagement, threats would multiply and our opportunities would narrow. (The White House, 1994)"

George Bush also stated that "Our response [on WMD] must take full advantage of strengthened alliances, the establishment of new partnerships with former adversaries, innovation in the use of military forces, modern technologies, including the development of an effective missile defense system, and increased emphasis on intelligence collection and analysis" (The White House, 2002). With the same spirit, Obama also reiterated that "if Iran meets its international obligations on its nuclear program, they will be able to proceed on a path to greater political and economic integration with the international community. If they ignore their international obligations, we will pursue multiple means to increase their isolation and bring them into compliance with international nonproliferation norms" (The White House, 2010).

The importance of International community engagement to counter against Iran nuclear threat has given a door open for under Bush administration to make an international deal with Iran which later completed in the Obama administration, which is the comprehensive Joint Comprehensive Plan of Action Deal (JCPOA) (Rogers, 2005). Under the support from IAEA, EU, and UNSC, JCPOA was further become U.S. foreign policy in responding to 
Iran nuclear threat in 2015 (The White House President Obama, 2016).

In contrast with Trump administration, U.S. intention to withdraw from JCPOA deal were not supported at all by international community such as EU and United Nations (EU, 2018) (United Nations, 2018). President Donald Trump met a lot of resistance from international community for U.S. to employ its new foreign policy towards Iran. It was notably that China, Russia and European leaders roundly condemned Donald Trump's intention to withdraw from the deal believing that it would only reflected the growing isolation of U.S. and threatened to destabilize the Middle East (Castle \& Erdbrink, 2017). United Nations through its Secretary General also expressed its deep concern that U.S. withdrawal would only create more problems for the stability in the Middle East (UN, 2018). This is where Donald Trump, as the leaders will play a key role in U.S. decision making process to extend whether or not the leaders will respond to the international pressure to not withdraw from JCPOA deal while at best continue to stop Iran to develop its nuclear weapon.

Nevertheless, in general, the stances of international community against Iran suspicious nuclear activity and its potential pursuit of nuclear weapons still stand the same way U.S. perceive to be a threat (Karacasulu \& Karakir, 2008). In the perspective of U.S. itself, under Trump administration, the strategic environment in the Middle East provided a huge concern for U.S. national interest, believing that Iran "support terrorist groups and openly calls for U.S. destruction. (The White House, 2017)" Thus, despite the current time U.S. having different perspective on how the world should deal with Iran nuclear development, both U.S. and International community believe that pressure against Iran to stop its nuclear development still relevant to stabilize the Middle East and to achieve Non-Proliferation Treaty objective.

\section{U.S. Commitment to protect Israel in Middle} East

If we observe carefully, U.S. strategic interest towards Middle East has been consistent over the period since the Bill Clinton administration until Trump administration. What really highlight the interest of U.S. in Middle East over the years lies on its commitment to protect Israel. Thus, letting Iran possessing nuclear weapons could provide a huge security concern for U.S. most important ally, which is Israel.

U.S. strong bond with the Israel has always been vital interest for U.S. strategic security interest (US Congressional Research Service, 2018). It needs to be taken into note that Israel is U.S. closest allies since the post world war II. Both countries have been close for decades based on the common democratic values, religious affinities, and security interests. In addition, Israel is a leading recipient of U.S. foreign aid and largest trading partner (US Congressional Research Service, 2018). In fact, according to Jim Zenotti (2018), a specialist in Middle Eastern affairs of U.S. congressional research service, U.S. officials and lawmakers often consider Israel's security as part of U.S. foreign policy.

We can actually see the proof from many of the speeches from Israeli prime ministers and requests to the U.S. government from Bill Clinton until Trump administration. In early July 1996, Prime Minister Netanyahu spoke in the congress attended by U.S. Vice Presidents and other executives stated that:

"The most dangerous of these regimes is Iran that has wed a cruel despotism to a fanatic militancy. If this regime, or its despotic neighbor Iraq, were to acquire nuclear weapons, this could presage catastrophic consequences, not only for my country, and not only for the Middle East, but for all mankind. I believe the international community must reinvigorate its efforts to isolate these regimes, and prevent them from acquiring atomic power." (Netanyahu, 1996) 
Following the Netanyahu speech, in September 1996, the congress and Clinton signed Iran Libya Sanction Act, which prohibited any companies to have business with Iran in energy sector (US Deparment of Treasury, 2019).

In Bush administration, the Israel pressure to act seriously on Iran nuclear threat and put more tough sanctions also can be demonstrated in the then Prime Minister (PM) Speech Ohud Olmet in the Joint Meeting of U.S. Congress and Executives in late May 2006. During his speech, PM Olmet reiterated that:

"Iran, the world's leading sponsor of terror, and a notorious violator of fundamental human rights, stands on the verge of acquiring nuclear weapons. With these weapons, the security of the entire world is put in jeopardy... If we don't take Iran's bellicose rhetoric seriously now, we will be forced to take its nuclear aggression seriously later." (Olmet, 2006)

The strong encouragement from Israel to U.S. to take serious measures toward Iran along with international community was demonstrated in the series of sanctions implemented in the Bush era such as but not limited to UNSC resolution $1803,1747,1835$, which have been done in the span of Bush era (US Deparment of Treasury, 2019).

In the Obama administration, PM Netanyahu had been in the forefront to keep pressure U.S. to not ease the sanctions against Iran. In July 2010, after President Obama and PM Netanyahu discusses issues regarding defense cooperation and security concerns in the Middle East, both of the leaders have shown their commitment to put tough sanctions to Iran. In the press conference, Obama stated that:

"I reiterated to the Prime Minister Israel that there is no change in U.S. policy when it comes to these issues. We strongly believe that Israel has unique security requirements. It's got to be able to respond to threats or any combination of threats in the region. And that's why we remain unwavering in our commitment to Israel's security. And the United States will never ask Israel to take any steps that would undermine their security interests... We have instituted through the U.N. Security Council the toughest sanctions ever directed at an Iranian government. In addition, last week I signed our own set of sanctions, coming out of the United States Congress, as robust as any that we've ever seen. Other countries are following suit. And so we intend to continue to put pressure on Iran to meet its international obligations and to cease the kinds of provocative behavior that has made it a threat to its neighbors and the international community." (Obama, 2010)

In the response, the PM Netanyahu responded Obama statement by saying that "I urge other leaders to follow the President's lead, and other countries to follow the U.S. lead, to adopt much tougher sanctions against Iran, primarily those directed against its energy sector. (Netanyahu, 2010)". Howver, when Obama made a JCPOA deal with Iran in 2015, PM Netanyahu was not in favor with it and has asked the U.S. government publicly that that Israel regrets the decision made by U.S.. Netanyahu then came to the U.S. congress and made a speech about the deal, saying that:

"Iran's nuclear program can be rolled back well-beyond the current proposal [JCPOA deal] by insisting on a better deal and keeping up the pressure on a very vulnerable regime, especially given the recent collapse in the price of oil. My friends, for over a year, we've been told that no deal is better than a bad deal. Well, this is a bad deal. It's a very bad deal. We're better off without it" (Netanyahu, Transcript of Netanyahu Remarks to Congress, 2015).

As soon as Donald Trump stepped up as the President of United States in 2016, Benjamin Netanyahu congratulate him and believe that Trump is a the "true friend of Israel” (Zion \& Winer, 2016) Donald Trump 
also has strong admiration toward Benjamin Netanyahu and both of them have similar stances on how U.S. should address Iranian nuclear threat (Maital, 2018). In fact, it was Benjamin Netanyahu who support and convinced Donald Trump to withdraw from the JCPOA deal. According to the Israeli television broadcaster Kan, Netanyahu stated that "We convinced the U.S. president [to exit the deal] and I had to stand up against the whole world and come out against this agreement ... and we didn't give up" (Netanyahu Cited in Middle East Monitor, 2018) In May 2018, Donald Trump officially withdrew from JCPOA deal and Israel was the one who defend the deal to international community despite its controversies. .

Based on the explanation above, it is plausible to say protecting Israel security interest has become huge consideration of U.S. to employ its foreign policy towards Iran. The pressure from Israel to keep pushing Iran in hard-line approach is also become the huge consideration of U.S. to be sterner on Iran foreign policy.

\section{U.S. Foreign Policy Toward Iranian Nuclear Threat: Change and Continuity} Bill Clinton Administration (1993-2001)

The early years of post-cold war era in United States foreign policy was led by Bill Clinton administration. Throughout his tenure, U.S. foreign policies towards Iran were heavily dominated by series of economic sanctions (Muray, 2010). Despite of that, Bill Clinton had several efforts to engage with Iran diplomatically in his second term despite it was failed in the end. Moreover, in his early years, Bill Clinton stated that "I put our effort to stop the proliferation of weapons of mass destruction at very top of our national security agenda" (Clinton B. , Remarks by President Bill Clinton On National Missile Defense, 2000). Based on this statement, it can be said that preventing nuclear proliferation was U.S. top priority foreign policy at that time.
In 1992, the U.S. intelligence reports concluded that Iran has worrying agenda about its nuclear weapon ambition (Joint Atomic Energy Intelligence, 1993). This is also supported by the comment of Iran's Defense minister, saying that a nonconventional solution was needed to deal with the U.S. threat (Muray, 2010). The U.S. concern that Iran might pursue its nuclear development more ambitious than before were also supported by Iran's breaching to UN sanctions, blocking the Peace Process, and acquiring missiles from North Korea (Myers, 1997) . U.S. state department labeled Iran as "the world's most terroristic state," believing that Iran has funded many rebel groups in the Middle East to create chaos in many states in the region (The White House, 1994).

Concerned by Iran situation, U.S. foreign policy under Bill Clinton administration employed a strategy so called as "Dual Containment" in 1993. Dual Containment was a policy which seeks to deal with both Iran and Iraq threats by isolating both countries regionally, cutting them off from the world economic and trading system (Myers, 1997). This strategy, according to U.S. National Security Strategy in 1994 has an aim as follows:

"As for Iran, our policy is aimed at changing the behavior of the Iranian government in several key areas, including its efforts to obtain weapons of mass destruction and missiles, its support for terrorism and groups that oppose the peace process, its attempts to undermine friendly governments in the region, and its development of offensive military capabilities which threaten our Gulf Cooperation Council (GCC) partners and the flow of oil. Pending changes in Iran's behavior, our goal is to contain and reduce its ability to threaten our interests. We also seek to coordinate with key allies to maximize pressures on Iran to change its course."

Donette Murray (2010) in his book "U.S. Foreign Policy on Iran" observed that Clinton administration embrace the idea 
that economics would be the main strength of U.S. to change states' behavior. Thus, as Murray emphasizes, Iran would be engaged economically in a bid to influence its regime behavior towards U.S. and other countries in the Middle East. This Dual Containment strategy toward encompasses several actions such U.S. military deterrent based in the Gulf States to contain Iran militarily, targeted economic sanctions to discourage foreign investment in Iran, as well as several diplomatic actions to discourage Iran support from developing nuclear weapons.

In 1997, a more moderate and progressive clerics, Mohammad Khatami was elected as Iran's new president. There was a hope from the White House that the relationship between the two governments can be improved under Khatami and hoping also that Iran can ease its stance to stop its nuclear weapon ambition. In his press conference as a new president, he announced that the failure to improve relation with U.S. was a "source of sorrow" to him and he promised that Iran would no acts against any effort to build peace in the Middle East (Muray, 2010). He even suggested that he was interested in having a dialogue with American people. Bill Clinton responded it with open arms; he made a speech to address Iranian people:

"To the people of Iran, I would like to say that the United States regrets the estrangement of our two nations. Iran is an important country with a rich and ancient cultural heritage of which Iranians are justifiably proud. We have real differences with some Iranian policies, but I believe these are not insurmountable... I hope that the day will soon come when we can enjoy once again good relations with Iran" (Clinton B. , Public Papers of the Presidents, 1997)

The new elected President Khatami has given U.S. hope to engage with Iran in a more diplomatic ways (Muray, 2010). During Clinton's second term, there were several efforts made by U.S. to improve the relationship. In October 1997, Clinton administration sent one message through Swiss Embassy in Teheran, which invited Iran to meet with U.S. officials without preconditions. However, Iran rejected the offer (Riedel, 2016). There was also another attempt in 1998 when U.S. vice president Al Gore asked Saudi Crown Prince Abdullah to be a broker for direct dialogue between two countries, however Iran once again rejected the offer (Muray, 2010). In May 1999, U.S. officials no longer put Iran as the world's leading state sponsor of terrorism in a hope that officials can ease relations with Iran along with several relaxed sanctions on sale of food and medicine (Muray, 2010).

According to the observation found by Riedel (2016), the special assistant to the President and the senior director for Near East and South Asian Affairs at the National Security Council during Clinton Administration, he found that "despite the despite the rebuffs, Khatami and Clinton continued to make public statements about the need to reconcile Iran and the United States" (Riedel, 2016). Moreover, the failure of both U.S. and Iran to engage in diplomatic actions was heavily influenced by both domestic politics in respected countries (Riedel, 2016). In Iran side, the constraint of its political structure hampered Khatami's willingness to improve the relation with U.S.. It comes out from the reason that in Iran's political structure, the Supreme Leader has the final say on ever decision of Iran, in which, every President's decision need the Supreme Leader's decision, which is coming from Khameini (Riedel, 2016). It was stated that CIA reported to U.S. policymakers that: "even if Khatami wanted to change Tehran's policy, the president probably lacked the authority to make the change without Khameini's approval." (CIA, 1997) In the side of U.S., the congress led by Republican and interest groups were pessimistic by Bill Clinton approach to engage with Iran, believing that Iran should be handled with hard line approach to make 
them unable to pursue nuclear weapon (Muray, 2010).

Based on the explanation above, we can understand that Bill Clinton administration foreign policy toward Iran nuclear threat were heavily filled with economic measures There was also several diplomatic approach to improve relationship between two countries and engage Iran's nuclear power on the table, but it Bill Clinton administration were constraint by internal politics in Iran and U.S. itself.

\section{George Bush Administration (2001-2008)}

As the successor of Bill Clinton Administration, U.S. foreign policy towards Iran under George Bush provided a mixture of series of diplomatic engagements as well as economic sanctions (Muray, 2010). Under Bush administration, Iran remains to be a dangerous threat to U.S. interest due to its intention to pursue a nuclear weapons and sponsoring terrorism in the Middle East, despite Mohammad Khatami's moderate and diplomatic approach to U.S. (The White House, 2002). Based on George Bush Speech, it was stated that:

"The Iranian issue is the strategic threat right now facing a generation of Americans, because Iran is promoting an extreme form of religion... And instability in that part of the world has deeply adverse consequences, like energy falling into the hands of extremist people that would use it to blackmail the West." (Bush, 2007)

The persona of Khatami as the moderate and progressive Iranian President at first had given a hope for Bush administration to pursue diplomatic approach (Muray, 2010). Secretary of State Powell believed that "it was time to try to reset the clock in U.S.-Iranian relations" (Clinton B. , 2004) Moreover, it was also believed that sanctions alone were not enough to change Iran's behavior. The assessment coming from U.S. officials believed that "the sanctions were ineffective and unnecessarily antagonistic towards America's allies" (Muray, 2010). In the Iranian side, there was also discussion by Iranian Majilis (congress) to set up direct talks with U.S., along with the support of Khatami (Muray, 2010).

When the incident of 9/11 happened, George Bush asked Iran to have cooperation with U.S. to destroy Taliban. As Iran also have historical hostility relations with Iraq and considering the Iraq's threat to Iran, Iran helped U.S. with open arms (Nader, Scotten, Rahmani, Stewart, \& Manhad, 2014). The U.S. made a foreign policy to create a diplomatic strategy helped by Iran to destroy Taliban. The diplomacy started to be initiated in the Afghanistan $6+2$ talks at the UN, Iranian made a promise to provide a search-and-rescue help, as well as assistance with planning, targeting, intelligence and cultural information (Muray, 2010). As the result, Iran helped U.S. to give information about hundreds of Al Qaeda suspects and forwarded copies of almost 300 of terrorist passports to U.S.. Satisfied with Iran help, U.S. foreign policy started to focus on offering Iran a deal involving specific concessions in exchange for cooperation (Leverett, 2008). It was found that State Department officials began to draft the National Security Presidential Decision which contained a proposal for diplomatic engagement (Parsi, 2008).

However, a sudden moment happened at the beginning of 2002, the Palestine freighter, MV Karine was intercepted by Israeli force carrying a huge cargo of arms. It was informed that Iran is the main sponsor of the Ship and had sent the large amount of weapons. The intention to propose a diplomatic engagement then delayed due to this event (Flyn, 2006). In 2002 , through Bush speech, Iran was named as the Axis of Evil, along with North Korea and Iraq, believing that these states have given grave threat to the security and stability of international community (Heradstveit \& Bonham, 2007). 
Despite having an intention to have diplomatic engagement, U.S. official concluded that Khatami as the Iranian President was too weak to engage diplomatically with U.S. in accordance to U.S. interest, due to the pressure from Iranian hardliners in the congress and its Supreme leader (Muray, 2010). Moreover, there is also intention that through Bush' speeches, the U.S. can further trigger the civilian in Iran particularly the reformers, students, and liberators in the favor of U.S. to pressure Iran government for the change regime (Muray, 2010). Iranian government was shock hearing U.S. speeches about the Axis of Evil, considering Iranian government has given U.S. unprecedented cooperation in the war against Iraq and Afghanistan, believing that U.S. speech is crude, simplistic, and unfair to them (BBC News, 2002).

In 2003, Iranian opposition group in exile held a press conference informed the world that Iran had a covert nuclear weapon programmed (IAEA, 2003). As the response, there was a consideration by Bush administration to put Military Operation on the table. However, this option was heavily unpopular in the U.S. domestic politics particularly from Democratic Party, despite Interest groups such as AIPAC endorse the option to strike Iran (Marsheimers \& Waltz, The Israel Lobby and US Foreign Policy, 2007).

In 2006, the new Iranian president, Mohammad Ahmadinejad was elected. In contrast with Khatami, Ahmadinejad was coming from conservative groups in Iran and have negative perception towards U.S. and the West (Haji-Yousefi, 2010). In his first speech in the UN, Ahmadinejad warned that In his first UN address, Ahmadinejad warned the U.S. and its allies that if some try to impose their will on the Iranian people through resort to a language of force and threat with Iran, we will reconsider our entire approach to the nuclear issue' (Ahmadinejad, 2005). In addition, Ahmadinejad even publicly stated in his speech in Iran that he would like to "wipe Israel off the map" (Fathi, 2005)

The hostile rhetoric brought up by the new elected Iranian President, Ahmadinejad, have made Iran-U.S. ties started to crack once again. The fact that Iran was not committed to IAEA regulation, its hostile activities by supporting terrorist groups and its rhetoric to attack Israel have brought U.S. nothing to but to consider more serious actions to handle Iran. George Bush through his book entitled "Decision Points," described Ahmadinejad as follow:

"Ahmadinejad steered Iran in an
aggressive new direction. The regime
became more repressive at home, more
belligerent in Iraq, and more proactive
in destabilizing Lebanon, the Palestinian
Territories, and Afghanistan... (Bush,
2010 )

In fact, military strike was an option in Bush administration. Former CIA and National Security Agency (NSA) chief Gen. Michael Hayden reported that George Bush and his inner circle were planning to develop a list of up to 2,000 bombing to nuclear facilities in Iran (Hayden, 2012). In the book entitled "Decision Points" written by Bush himself, he acknowledged that he had military option in plan to "stop the bomb clock, at least temporarily." However, according to his confession, he was influenced by domestic pressure believing that "destroying regime's prized project would embolden the opposition and would stir up Iranian nationalism and unite the people against U.S." (Bush, 2010) In addition, the military option was also heavily constrained by U.S. domestic politics and the fact that most of the Iranian people according to the poll were in favor of U.S. government to have better relations with U.S. (Steven Kull, 2007).

After discussion with his national security team and consulted with Vladimir Putin, Angela Merkel, and Tony Blair, Bush concluded that a series of international economic sanctions along with the proposal to have a grand deal will work to contain 
Iran nuclear program Moreover, the U.S. also involving EU, Russia, and China to talk with Iran in a hope that Iran can halt its nuclear enrichment program (Bush, 2010). The end goal of this talk was to ensure Iran halt is nuclear enrichment program and ensure that Iranian nuclear activity can be inspected by IAEA regularly in exchange for several relaxations from UNSC and U.S. sanctions (European Union, 2006). Despite of it, the talk had yet to achieve any significant deal during Bush Administration (Muray, 2010). However, the initiation to talk represented an important moment for the historical progress on the later Joint Comprehensive Plan of Action deal done by President Obama in 2015.

\section{Barrack Obama Administration (2008- 2016)}

Barrack Obama entered the White House replacing George Bush leadership in U.S. foreign policy on November 2008. During his early years, U.S. stances on Iran remains the same, which still become U.S. top priority to its foreign policy. Based on the U.S. National Security Strategy 2010, U.S. emphasized that "there is no greater threat to the American people than weapons of mass destruction, particularly the danger posed by the pursuit of nuclear weapons by violent extremists and their proliferation to additional states" (The White House, 2010) Moreover, U.S. foreign policy under Obama Administration continued the legacy of its previous administrations, which is to pressure Iran through economic sanctions, but in the same time offer the country a series of diplomatic engagements in a hope that Iran could stop its ambition over the nuclear weapon (Jahanbegloo, 2009).

$$
\text { However, under Obama }
$$

Administration, U.S. foreign policy emphasizes its commitment to build stronger foundation for U.S. leadership through several means; Engaging international community, respecting international law, and galvanizing the collective actions. These means, according to U.S. National Security Strategy, can be the best effort to stop the spread of nuclear weapons and nuclear materials based on the respect to the global common interest (The White House, 2010).

Based on that principle, U.S. foreign policy under Obama Administration had been using the Non-Proliferation Treaty as its channel to engage with Iran accountable for its suspicious nuclear activity. Therefore, Obama administration strongly relies on the diplomatic actions, as it is believed that it is fundamental to U.S. national security as U.S. defense capability (The White House, 2010). Specifically for preventing Iranian pursuit of nuclear weapons, it was stated in U.S. national security strategy 2010,

"The United States will pursue to prevent Iran from developing a nuclear weapon. If Iran meets its international obligations on its nuclear program, they will be able to proceed on a path to greater political and economic integration with the international community. If they ignore their international obligations, we will pursue multiple means to increase their isolation and bring them into compliance with international nonproliferation norms. At the same time, our engagement must be both comprehensive and strategic. It should extend beyond nearterm threats by appealing to peoples aspirations for justice, education, and opportunity and by pursuing a positive and sustainable vision of U.S. partnership with the region."

Based on the explanation above, we can clearly see that U.S. foreign policy under Obama administration really emphasizing the international norms and collective action to curb Iran from pursuing its nuclear weapons. These kinds of actions actually have been similar from what we see in the previous administrations in the Clinton and Bush era. However, this time, Obama really had clear plan in mind and not merely a reactionary policy as what the other previous administrations done. 
At the initial steps, Obama started to use sanctions against Iran as a part to push Iran to get in the deal offered by U.S. in the earlier proposal under Bush Administration along with EU, Russia and China (McCormick, 2011). In early June 2010, UNSC passed a resolution to impose sanctions including expanding arms embargo and tightening restriction on financial and shipping enterprises related to "proliferation-sensitive activities" (UNSC, 2010). Moreover, U.S. also imposed economic sanctions through congressional legislation which entail to restrict foreign banks that deal with Iranian banks and any financial access to the U.S. financial system. In addition, the sanction also including restriction on gasoline suppliers that used to have business with Iran (US Department of State, 2019). Not only U.S. and UNSC, European Union also added several sanctions towards Iran which encompasses dual-use goods and technology, restrictions on trade in technology nuclear related, restriction on investment in Iranian oil and gas, transfer of funds, insurances, and ships and cargo aircraft (European Union, 2010). All of these actions were part of U.S. strategy to push Iran to have a deal with international community regarding its nuclear development (McCormick, 2011). The result gave an enormous impact towards Iran Economy. Based on the report from U.S. Government Accountability Office in 2013, it was reported that U.S. and International Sanctions have adversely affected the Iranian economy (US Government Accountability Office, 2013). This report has give a great result from Obama administration as leverage and initial step to begin bilateral and multilateral talk with Iran over the grand bargain of the nuclear deal.

In March 2013, it was reported that U.S. began to hold series of bilateral talks with Iranian officials in Oman concerning about the possibility to have a grand deal about Iranian nuclear development (McCormick, 2011). When Hassan Rouhani, the more moderate and pragmatic politician was elected as Iranian President in June 2013, the new President responded the intention with U.S. in a serious way (Rouhani Should Give Priority to Religious Freedom in Iran, 2013). On September 2013, for the first time ever since the Iranian revolution, Obama and Rouhani had a telephone conversation talking about the serious negotiations with the West on the Iranian Nuclear programmed (Mason \& Charbonneau, 2013).

The interim agreement was signed on November 2013 after several rounds of negotiations. In this interim agreement, seven actors were involved in the deal, which are United States, Great Britain, France, Russia, China, and European Union along with Iran (Arms Control Association, 2019). The agreement, so called as Joint Plan of Action called Iran to suspend its nuclear program in a short time in exchange for lifting several economic sanctions with the intention that Iran also willingly to continue to work in a long-term agreement. In addition, IAEA will employ to inspect Iranian nuclear facility a more intrusive and frequent manner. The agreement was formally implemented on January 2014 (Arms Control Association, 2019). On February 2014, it was reported that Iran was complying with the deal. The deal reported by IAEA inspection stated that Iran was implementing the agreed terms by halting its enrichment program 20 percent, blending down half of its stockpile for 20 percent to only 3.5 , as well as halting the work in its Arak Heavy Water Reactor. Satisfied with Iran's compliance, U.S. and European Union waive specific sanctions in Iranian Oil business (Arms Control Association, 2019). Moreover, it was reported that all parties agreed to continue their talks into more comprehensive one, which later called as The Joint Comprehensive Plan of Action (Arms Control Association, 2019).

Under this agreement, it was stated Iran must limit its nuclear development in 
several ways. First, Iran has to decrease its low-enriched uranium stockpile by 98 per cent. Second, the agreement will remain for fifteen years. Third, during the time period, Iran will only use its enriching uranium only for 3, 67\% enough for the civilian purposes (The White House, 2015). The Joint Comprehensive Plan of Action was remarkably agreed by Iran and supported by United Nations, EU, IAEA and major countries such as Russia, China, UK, and France (UN, 2015). The agreement was reached on April 2015 in Switzerland. In return, several of UNSC sanctions as well as EU and U.S. economic sanctions will be gradually lifted if Iran obeys the agreement. Despite of that, several sanctions will be remained uphold such as sanctions on missile technologies and conventional weapons, terror list sanctions, and ballistic missiles (Arms Control Association, 2019).

In addition, Iran should also need to submit its report nuclear development to the IAEA for the inspection program (The White House, 2015). In July 2015, the all relevant parties signed the agreement and become the first official deal with Iran about nuclear development since Iranian revolution in 1979 (Arms Control Association, 2019). Despite having big constraint in the internal politics such as the congress dominated by Republic and strong resistance from AIPAC, the deal become Obama's signature of U.S. foreign policy in his era.

\section{Donald Trump Administration (2016-2018)}

Since the beginning of the new administration, Donald Trump and the team has been bold and firm towards its stance on Iran, U.S. under Trump see Iran as the legitimate threat (The White House, 2017). U.S. perceive Iran as the rogue regimes whose action only provides instability to Middle East. The Iranian government is seen as the radical regime that creates destruction, death, and chaos all around the world. Moreover, Iran is seen as the states who sponsored a lot of terrorist activities and growing its network through proxies and pursuing missile program in any possible means and they have increased their efforts to hostility by expanding coercion, violating states' sovereignty, exploiting ambiguity, and "deliberately blurring the lines between civil and military goals" (Department of Defense, 2018).

In fact, U.S. believes that Iran aggression still continues as they see them sponsoring and giving assistance to the terrorist groups such as al Qaeda, Hezbollah, Hamas, and Taliban. The development, deployment, and proliferation of missiles are also seen as the grave threat to U.S. security interests. Iran harasses U.S. ships and threatens the freedom of navigation in the Red Sea and Arabian Gulf. Iran is deemed to launch cyberattack against U.S. critical infrastructure system and imprisons many American citizens on false charges (Department of Defense, 2018).

Based on the National Security Strategy (2017), U.S. strategy to counter Iran nuclear threat is focusing on two parts: (1) Neutralizing Iran's destabilizing influence, and (2) constraining its aggression particularly for Iran support in terrorism. The way U.S. do its strategy is through using economy and military leverage to maximizing its pressure towards Iran (The White House, 2017). In addition, U.S. are also willingly to revitalize its traditional alliances and regional partnerships in order to restore more balance in the favor of U.S. interest (The White House, 2017). Despite U.S. is little bit unclear on what kind of measures that it will take to revitalize its allies partnership while at the same time demand for reciprocity, it is safe to assume that both U.S. and its allies has common interest to counter Iran threat and thus cooperate together to counter Iran's activity and its support for terrorist proxies in the Middle East. The last thing that U.S. will do is to deny all paths of Iran's chances in acquiring nuclear weapon by any means even a slightest chance. 
In May 8 2018, U.S. officially withdrew from JCPOA deal. U.S. perceive that there is a loophole in JCPOA deal that gives a chance for Iran to pursuing its nuclear weapon capability. As the U.S. administration under Donald Trump firmly take a principled realism approach, it is not hard to understand the very reason U.S. would abandon the diplomatic deal that have been agreed just in 2015. The agreement can be safely assumes that it does not represent the current U.S. stances, which believes in that tangible power should be used to curb Iran's nuclear. It also has to taken into note that U.S. under Trump really emphasize the current world as a competition, where states can only either be the loser or the winner. This idea of competition seems very familiar with what Donald Trump has in mind written in many of his previous book in the America We Deserved (200), and Crippling America (2004), in which believes that the world is in competition and there is either a winner or loser, and U.S. is currently "losing". If we observed carefully, the idea of winner or loser also fits well with Donald Trump's tendency in binary thinking as what I have explained before in the chapter III.

Moreover, according to The White House (2017), there are four points that makes U.S. decide to withdraw from the JCPOA deal. Firstly, the JCPOA deal is deemed fail to manage the other threat from Iran as it is keep supporting the terrorist proxies and being hostile to its neighbors. According to U.S., even when Iran signed the JCPOA deal, it has continued its effort in supporting the dictatorship of Basher alAssad in Syria, supporting the escalation of civil war in Yemen as it use proxy to attack other nations, and enables Hezbollah to build arsenal weapons that threaten U.S. most important allies, which is Israel (The White House, 2018).

Second, U.S. under Trump administration believed that the JCPOA deal did not provide enough strong mechanism for inspections and verification. U.S. under
Trump administration believed that the deal should have given requirement for Iran to allow inspections anytime and anywhere whenever international inspectors requested (The White House, 2018).

Third, U.S. under Trump administration believe that the JCPOA would only give access to Iranian regime in gaining a huge amount of money as the result of lifted economic sanctions (The White House, 2018). As the result, U.S. believed that Iran would increase its economic and military advantage in the region just to get more leverage in dealing with the international community to acquire nuclear weapons once the deal exhausted. In fact, U.S. perceived that Iran used the money to fund military buildup and terrorist proxies for Hezbollah and Hamas (Trump cited in the White House, 2018).

Fourth, U.S. believed that the JCPOA deal does not provide any requirements to the Iran's ballistic missile program, in which something that Iran has been developed for decades (The White House, 2018). Hence, JCPOA deal under U.S. perspective is not adequate to counter Iran threat in Middle East. This is where U.S. under Donald Trump administration believes that Iran is actually violate the spirit of the JCPOA deal by developing its missile program and threatening Israel and other U.S. allies through its support for Hezbollah and Hamas (Trump cited in the White House, 2018).

Last but not least, the JCPOA deal has limited time, which is only last for fifteen years. This is where U.S. under Trump administration cannot accept the deal at all. U.S. believed that the deal only delay Iran's ambition to acquire nuclear weapon as U.S. skeptical about any agreement once the deal is expired (Trump cited in the White House, 2018). After the expiration, U.S. believed that Iran would pursue its nuclear once again and that time will be easier since the economic condition of Iran will be relieved due to the lifted economic sanctions by 
International community (The White House, 2018). Regardless, Donald Trump believed that Iran will always be U.S. enemy as long as the "religion fanatic regime" is governing Iran. Thus, looking at the U.S. perspective, Iran will always be the enemy of United States when the Iran supreme leader is still in the power (Trump cited in the White House, 2018).

\section{From Bill Clinton to Trump Administration: Change and Continuity}

U.S. foreign policies toward Iranian nuclear threat have revolved around unilateral economic sanctions, diplomatic engagements, and international cooperation as a means to stop Iran from its nuclear weapon ambition. If we observe it carefully, we can understand that since the era of Bill Clinton until Obama Administration, there is a consistent pattern that U.S. would use "stick and carrot" approach towards Iran. It works in a way that U.S. would impose many economic sanctions or pressure diplomatically but in the same time U.S. would also ease its sanctions and improve its relation with Iran if Iran has an effort to stop its nuclear weapon development.

However, there is a significant change of U.S. foreign policy under Donald Trump, where he decided to wihtdraw from the deal and apply maximum pressure to stop Iranian deal. This era marked $s$ a clear sign that the foreign policy under Trump administration has contrast view with its previous administrations in particular to the Obama administration in perceiving Iran. Under Obama, it is stated that U.S. clear preference is to deal with Iran issue is through a peaceful diplomatic resolution (White House, 2015). In contrast with Trump administration, Iran nuclear threat should be handled through economic coercion in order to cripple its ability to advance its nuclear capability (White House, 2018).

U.S. Foreign policy shift towards Iran has been seen as an odd decision for the U.S. strategic interest (Allison, 2018). Dan Smith (2019), director of Stockholm International Peace Research Institute (SIPRI) believed that the withdrawal will only undermine U.S. credibility and leadership in multilateral diplomacy. Moreover, the withdrawal also challenges the UNSC authority in particular to its abiding resolution to endorse the JCPOA deal. As the global power who asserts leadership to shape the strategic interest around the world, it is a huge loss for the U.S. to be inconsistent in historical Iran nuclear deal (Smith, 2019).

From the point above, it can be understood that the inconsistency of U.S. foreign policy under Trump administration with U.S. foreign policy in previous administrations could harm many of U.S. interests. For example, it could damage the U.S. image in the international community or it could discourage the trust from Iran and other major parties in making the significant deal to reduce the Iranian nuclear weapon development. Social Scientist expert from Harvard University, Graham Allison (2018) event stated that "The decision will most likely lead to an outcome that is much worse not only for the U.S. but also for Israel." With being said, we argue that U.S. foreign policy towards Iran should be held consistent and create a clear vision on how U.S. should engage Iran in order to be able to provide the Iranian trust to create a diplomatic deal as well as to gain credibility from international community in regard to U.S. foreign policy. To make it easier to understand, we provide the change and continuity of U.S. foreign policy towards Iran on the figure below: 
Table 2

Change and Continuity of US Foreign Policy toward Iran Nuclear Weapon Ambition

\begin{tabular}{|c|c|c|}
\hline Administration & $\begin{array}{l}\text { U.S. Foreign Policy to Iran } \\
\text { Nuclear Weapon Ambition }\end{array}$ & Note \\
\hline Bill Clinton (1993-2001) & $\begin{array}{l}\text { Dual Containment (1st } \\
\text { period), Normalize } \\
\text { Relationship (2nd Period) }\end{array}$ & $\begin{array}{l}\text { Isolating Iran economically and } \\
\text { diplomatically to exhaust its } \\
\text { willingness to pursue nuclear } \\
\text { development ( } 1 \text { st period). When } \\
\text { Khatami stepped up, there were } \\
\text { serious efforts to engage Iran } \\
\text { diplomatically (2nd period) }\end{array}$ \\
\hline $\begin{array}{l}\text { George Bush (2001- } \\
\text { 2008) }\end{array}$ & $\begin{array}{l}\text { Stern of Economic Sanctions } \\
\text { (1st period) and Proposal of } \\
\text { International Deal (2nd } \\
\text { period) }\end{array}$ & $\begin{array}{l}\text { Aim to change Iranian regime } \\
\text { through crippling its economy } \\
\text { initially, but then change plan to } \\
\text { offer Iran a grand deal with EU, } \\
\text { Russia, and China. }\end{array}$ \\
\hline $\begin{array}{l}\text { Barrack Obama (2008- } \\
\text { 2016) }\end{array}$ & $\begin{array}{l}\text { International Pressure (1st } \\
\text { period), Diplomatic } \\
\text { engagement, and JCPOA deal } \\
\text { (2nd period) }\end{array}$ & $\begin{array}{l}\text { Engage International Community to } \\
\text { Pressure Iran economically but at } \\
\text { the same time offer Iran the JCPOA } \\
\text { deal (The continuance of Bush } \\
\text { Proposal) }\end{array}$ \\
\hline $\begin{array}{l}\text { Donald Trump (2016- } \\
\text { 2018) }\end{array}$ & Maximum Pressure & $\begin{array}{l}\text { Withdraw from JCPOA Deal. Re- } \\
\text { impose economic sanctions. }\end{array}$ \\
\hline
\end{tabular}

Source: Authors, 2020.

\section{CONCLUSION}

U.S. foreign policy has experienced changes and continuity since Bill Clinton Administration to Trump Administration. In making the decision, each administration faced its own unique strategic environment in the internal and international level. Most of the times, the internal environment were heavily influenced by the domestic politics in particular from Democrat and Republican party as well as the lobby from interest groups in particular the israeli groups. Meanwhile in the international level, there are similiar patterns that U.S. tried to maintain its commitment to protect key allies in the Middle East such as Israel and Gulf Countries but at the same time being

\section{BIBLIOGRAPHY}

Ahmadinejad, M. (2005, September 17).

"Address by H.E. Dr. Mahmood encouraged by international community to stop Iranian nuclear threat in a diplomatic manner.

Since Bill Clinton until Obama administraiton, the U.S. foreign policy has consistent pattern in the way that U.S. would push for economic sanctions towards Iran but at the same time try to engage Iran in diplomatic manner to stop its nuclear weapon program. However, Donald Trump administraiton provided significant changes of direction on where U.S. envision its means to Iran, which it has been proven by its decision to withdraw from JCPOA deal and applying maximum economic pressure towards Iran.

Ahmadinejad." Retrieved October 24, 2019, from United Nations: https://www.un.org/webcast/ga/60/s tatements/iran050917eng.pdf 
AIPAC. (2019). What We Have Achieved. Retrieved November 5, 2019, from About: https://www.aipac.org/aboutaipac2/what-weve-accomplished

Alexander George, A. B. (2005). Case Studies and Theory Development in Social Sciences. Massachussets: MIT Press.

Ali, I. (2017, September 7). Top U.S. general says exiting Iran nuclear pact would make future deals tough. Retrieved December 17, 2019, from https://www.reuters.com/article/usiran-nuclear-usa/top-u-s-general-saysexiting-iran-nuclear-pact-would-makefuture-deals-tough-idUSKCN1C12OF

Arms Control Association. (2019). Timeline of Nuclear Diplomacy with Iran. Retrieved September 10, 2019, from Arms Control Association: https://www.armscontrol.org/factshee t/Timeline-of-Nuclear-DiplomacyWith-Iran

Arms Control Association. (2019). Timeline of Nuclear Diplomacy with Iran. Retrieved September 10, 2019, from Arms Control Association: https://www.armscontrol.org/factshee t/Timeline-of-Nuclear-DiplomacyWith-Iran

Arms Control Association. (2019, November). Timeline of Nuclear Diplomacy with Iran. Retrieved November 18, 2019, from https://www.armscontrol.org/factshee t/Timeline-of-Nuclear-DiplomacyWith-Iran

BBC. (2017, September 20). Iran's leader Hassan Rouhani slams Donald Trump in UN speech. Retrieved November 25 , 2019, from https://www.bbc.com/news/worldmiddle-east-41340294

BBC News. (2002, January 31). IIran Lashes out at Bush. Retrieved October 28, 2019, from BBC News:

http://news.bbc.co.uk/2/hi/middle_ea st/1793856.stm

Bojang. (2018). The Study of Foreign Policy in International Relations. Journal of Political Sciences \& Public Affairs, 1-9.

Borger, J. (2007, July 16). Cheney pushes Bush to Act on Iran. Retrieved October 17, 2019, from The Guardian: https://www.theguardian.com/world/ 2007/jul/16/usa.iran

Braun, V., \& Clarke, V. (2006). Using thematic analysis in psychology. Qualitative Research in Psychology , 77-101.

Brzezinski, Z. (1997). Differentiated Containment: U.S. Policy Toward Iran and Iraq. New York: Council on Foreign Relations Press.

Bush cited in the White House. (2002, September). The National Security Strategi of the United States of America. Retrieved December 16, 2019, from Historical Office: Office of the Secretary of Defense:

https://history.defense.gov/Portals/70 /Documents/nss/nss2002.pdf?ver $=201$ 4-06-25-121337-027

Bush cited in the White House. (2006, March). A National Security Strategy For A Global Age. Retrieved December 16, 2019, from Historical Office: Office of the Secretary of Defense:

https://history.defense.gov/Portals/70 /Documents/nss/nss2006.pdf?ver=201 4-06-25-121325-543

Bush, G. (2002, December). National Strategy to Combat Weapons of Mass Destruction. Retrieved October 17, 2019, from Homeland Security Digital Library: https://www.hsdl.org/?view\&did=860

Bush, G. (2010). Decision Points. New York: Crown Publishing Group.

Castle, S., \& Erdbrink, T. (2017, October 13). European Leaders Criticize Trump's Disavowal of Iran Deal. Retrieved October 24, 2019, from New York Times:

https://www.nytimes.com/2017/10/1 3/world/europe/trump-iran-nucleardeal.html

CIA. (1997, December 22). Memorandum: Hezbollah Reactions to Khatami's Election. CIA. Retrieved from CIA.

CIA cited in Murray. (2010, December 22). US Foreign Policy and Iran: AmericanIranian Relations since the Islamic Revolution. New York: Routledge. Retrieved from CIA.

Clinton cited in The White House. (1994). A National Security Strategy of Engagement and Enlargement. Retrieved December 16, 2019, from Historical Office: Office of the Secretary 
of Defense:

https://history.defense.gov/Portals/70

/Documents/nss/nss1994.pdf?ver=201

4-06-25-121219-500

Cohen, Z. (2018, March 17). National security veterans urge Trump not to scrap Iran nuclear deal. Retrieved October 17, 2019, from CNN News:

https://edition.cnn.com/2018/03/27/ politics/experts-trump-iran-nuclearletter/index.html

Congress.Gov. (2019). House Foreign Affairs Committee. Retrieved December 16, 2019, from Congress.Gov: https://www.congress.gov/committee /house-foreignaffairs $/ \mathrm{hsfa00}$ ?searchResultViewType $=$ expanded

Congressional Research Service. (2018, May 8). US Decision to Cease Implementing the Iran Nuclear Agreement. Retrieved September 29, 2019, from Congressional Research Service: https://fas.org/sgp/crs/nuke/R44942. pdf

Crowley, M. (2017, 12 28). How Trump could kill the Iran nuclear deal in January. Retrieved October 10, 2019, from Politico: https://www.politico.com/story/2017 /12/28/trump-kill-iran-nuclear-deal260860

Davis, J. (2017, Jult 17). Pro-Israel AIPAC Creates Group to Lobby Against Iran Deal. Retrieved October 17, 2019, from New York Times: https://www.nytimes.com/politics/firs t-draft/2015/07/17/pro-israel-aipaccreates-group-to-lobby-against-theiran-deal/

Deibel, T. L. (2007). The International Strategic Environment. Dalam T. L. Deibel, Foreign Affairs Strategy: Logic for American Statecraft (hal. 35-76). Cambridge: Cambridge University Press.

Department of Defense. (2018). Summary of the 2018 National Defense Strategy of the United States of America. Retrieved December 16, 2019, from Department of Defense: https://dod.defense.gov/Portals/1/Do cuments/pubs/2018-National-DefenseStrategy-Summary.pdf
Department of Defense. (2019). Chairman of the Joint Chief of Staff. Retrieved December 17, 2019, from https://www.defense.gov/ourstory/meet-the-team/chairman-of-thejoint-chiefs-of-staff/

Department of Defense. (2019). The Role: Secretary of Defense. Retrieved December 17, 2019, from https://www.defense.gov/OurStory/Meet-the-Team/Secretary-ofDefense/

Department of Defense United States of America. (1994). National Security Strategy Archive. Retrieved September 13, 2019, from National Security Strategy Reports 1992-2017: http://nssarchive.us/

Department of Defense United States of America. (2017). National Security Strategy Archive. Retrieved September 13, 2019, from National Security Strategy Reports 1992-2017: http://nssarchive.us/

Department of State. (2019). About Department of State. Retrieved December 17, 2019, from https://www.state.gov/about/aboutthe-u-s-department-of-state/

EU. (2018, 08 05). Remarks by HR/VP Mogherini on the statement by US President Trump regarding the Iran nuclear deal (JCPOA). Retrieved October 24, 2019, from European Union External Action: https://eeas.europa.eu/headquarters/ headquartershomepage/44238/remarks-hrvpmogherini-statement-us-presidenttrump-regarding-iran-nuclear-dealjcpoa_en

European Union. (2006). Elements of a proposal to Iran as approved on 1 June 2006 at the meeting in Vienna of China, France, Germany, the Russian Federation, he United Kingdom, the Unites States of America and the European Union . Retrieved October 28, 2019, from Council of the European Union: https://www.consilium.europa.eu/ueD ocs/cms_Data/docs/pressdata/en/rep orts/90569.pdf

European Union. (2010, October 27). COUNCIL REGULATION (EU) No 961/2010 of 25 
October 2010 on restrictive measures against Iran and repealing Regulation (EC) No 423/2007. Retrieved October 27, 2019, from Official Journal of the European Union: https://eurlex.europa.eu/LexUriServ/LexUriServ.d o?uri=OJ:L:2010:281:0001:0077:EN:PD $\mathrm{F}$

Fathi, N. (2005, October 17). Wipe Israel 'off the map' Iranian says. Retrieved October 24, 2019, from The New York Times: https://www.nytimes.com/2005/10/2 7/world/africa/wipe-israel-off-themap-iranian-says.html

Flyn, L. (2006). Dealing with Tehran: Assessing US Diplomatic Options toward Iran. New York: A Century Foundation Report.

Frank, D. J. (2018). Trump on the Couch: Inside the Mind of the President. New York: Avery Press.

Frank, J. (2018, September 25). I used applied psychoanalysis to assess President Trump. The diagnosis is frightening. Retrieved December 22, 2019, from Stat News: https://www.statnews.com/2018/09/ 25/donald-trump-appliedpsychoanalysis-diagnosis/

Gould, J., \& III, L. S. (2017, October 7). Key Republicans, Dems blast Trump's surprise withdrawal from Syria. Retrieved October 17, 2019, from Defense News: https://www.defensenews.com/congre ss/2019/10/07/key-republicansdems-blast-trumps-surprise-syriawithdrawal/

Gulf Cooperation Council. (2019). Iranian Crisis. Retrieved November 5, 2019, from Major achievements in the field of foreign policy: https://www.gccsg.org/enus/CooperationAndAchievements/Achi evements/PoliticalAffairs/Majorachiev ementsinthefieldofforeignpolicy/Pages /Iransnuclearcrisis.aspx

Guttman. (2007). Iran's Pursuit of Nuclear Weapons. Retrieved October 17, 2019, from AIPAC: https://www.aipac.org//media/publications/policy-andpolitics/aipac-analyses/issuememos/2007/01/irans_pursuit_of_nucl ear_weapons.pdf
Haji-Yousefi, A. M. (2010). Iran's Foreign Policy during Ahmadinejad: From Confrontation to Accommodation. Annual Conference of the Canadian Political Science Association (hal. 1-21). Montreal: Concordia University.

Hayden, M. (2012, January 12). Bush's CIA director: We determined attacking Iran was a bad idea. Retrieved November 05, 2019, from The Foreign Policy: https://foreignpolicy.com/2012/01/19 /bushs-cia-director-we-determinedattacking-iran-was-a-bad-idea/

Heradstveit, D., \& Bonham, G. M. (2007). What the Axis of Evil Metaphor Did to Iran. MIDDLE EAST JOURNAL M Volume 61, No. 3, 421-439.

Hill, C. (2003). The Changing Politics of Foreign Policy. New York: Palgrave McMillian.

Ho, C. (2015, July 21). AIPAC spent record $\$ 1.7$ million as it lobbied Congress to review Iran deal. Retrieved October 10, 2019, from The Washington Post:

https://www.washingtonpost.com/ne ws/powerpost/wp/2015/07/20/aipac s-lobbying-spending-spikes-as-grouppushes-hard-to-oppose-iran-deal/

Hoffman, P., \& Lantis, J. (2019). The Battle for U.S. Foreign Policy: Congress, Parties, and Factions in the 21st Century. New York: Springer Nature.

Hunt, J. (2017). Nuclear Arms Control in US Foreign Policy. Dalam J. Butler, Oxford Research Encyclopedia of American History. Oxford: Oxford University Press.

IAEA. (2003, June 19). Implementation of the NPT safeguards agreement in the Islamic Republic of Iran. Retrieved October 24, 2019, from IAEA Reports: https://www.iaea.org/sites/default/fil es/gov2003-40.pdf

IAEA. (2003). Report by the Director General. Doc. GOV/2003/75.

Iran Data Portal. (1979, November 5). Speech (On American Conspiracies). Retrieved September 9, 2019, from Iran Data Portal:

http://irandataportal.syr.edu/speechon-american-conspiracies

Jahanbegloo, R. (2009, June). The Obama Administration and Iran:Towards a Constructive Dialogue. Retrieved October 28, 2019, from The Centre for 
International Governance Innovation: https://www.files.ethz.ch/isn/101207 /WP_43-web_0.pdf

Joint Atomic Energy Intelligence. (1993). Lofty Goals, meagre beginnings. Iran's nuclear program: building a weapons capability'. Director of Central Intelligence.

Karacasulu, Z. N., \& Karakir, I. A. (2008). Attitutes of International Community Towards Iran's Nuclear Puzzle. Journal of International and Area Studies, Vol. 15, Number 2, 1-19.

Karakir, Z. N. (2008, December). Attitudes of the International Community toward Iran's Nuclear Puzzle. Journal of International and Area Studies, 1-19. Retrieved 2019, from Zehra Nilufer Karacasulu and Irem Askar Karakir. Kodufayur, V. (2018, May 14). Ripples in the Gulf: GCC States' Reaction to Withdrawal from Iran Deal Reflects Disunity. Retrieved 20, from Foundation for Defense Democracy.

Leverett, H. M. (2008, October 7). Iran Gave US Help on Al-Qaeda after 9/11. Retrieved October 28, 2019, from CBS News: https://www.cbsnews.com/news/irangave-us-help-on-al-qaeda-after-9-11/

Maital, S. (2018, March 9). The Striking Similarities between Trump and Netanyahu. Retrieved from Jerusalem Post: https://www.jpost.com/JerusalemReport/The-striking-similaritiesbetween-Trump-and-Netanyahu544468

Marcos, C. (2015, November 9). House rejects Obama's Iran deal. Retrieved October 17, 2019, from The Hill: https://thehill.com/blogs/flooraction/house/253370-house-rejectsiran-deal

Marsheimer, J. (2001). The tragedy of Great Power Politics. New York: Norton.

Marsheimers, J., \& Waltz, K. (2007). The Israel Lobby and US Foreign Policy. New York: Farrar, Straux \& Giroux.

Mason, J., \& Charbonneau, L. (2013, September 13). Obama, Iran's Rouhani hold historic phone call. Retrieved October 28, 2019, from Reuters: https://www.reuters.com/article/usun-assembly-iran/obama-irans- rouhani-hold-historic-phone-callidUSBRE98Q16S20130928

Mattis Cited in The Hill. (2018, April 28). Mattis defends Iran deal as Trump considers withdrawal. Retrieved December 27, 2019, from https://thehill.com/policy/defense/38 5094-mattis-defends-iran-deal-astrump-considers-withdrawal

McCormick, J. M. (2011). The Obama Presidency: A Foreign Policy of Change. Transforming America: Barack Obama in the White House, pp. 235- 266.

Memoli, M. (2019, June 20). Biden once warned a president: War with Iran without congressional approval is impeachable . Retrieved October 17, 2019, from NBC News:

https://www.nbcnews.com/politics/20 20-election/biden-once-warnedpresident-war-iran-withoutcongressional-approval-impeachablen1019041

Milner, H., \& Tingley, D. (2015). Sailing the Water's Edge: The Domestic Politics of American Foreign Policy. New Jersey: Princeton University Press.

Muray, D. (2010). US Foreign Policy and Iran. New York: Routledge.

Myers, H. (1997). The US Policy of Dual Containment Toward Iran and Iraq in Theory and Practice. Alabama: Air War College Air University.

Nader, A., Scotten, A. G., Rahmani, A. I., Stewart, R., \& Manhad, L. (2014). Iran's Influence in Afghanistan: Implications for the U.S. Drawdown. California: RAND Corporation.

Netanyahu Cited in Middle East Monitor. (2018, July 18). Netanyahu: Israel convinced Trump to exit Iran nuclear deal. Retrieved December 28, 2019, from Middle East Monitor: https://www.middleeastmonitor.com/ 20180718-netanyahu-israel-convincedtrump-to-exit-iran-nuclear-deal/

Netanyahu, B. (1996, July 10). PM NetanyahuSpeech to US Congress- . Retrieved November 5, 2019, from Israel Ministry of Foreign Affairs :

https://www.mfa.gov.il/mfa/mfaarchive/1996/pages/pm\%20netanyah u- 
$\% 20$ speech $\% 20$ to\%20us $\% 20$ congress\%20july\%2010-\%201996.aspx

Netanyahu, B. (2010, July 6). Remarks by PM Netanyahu and US President Obama. Retrieved November 5, 2019, from Israel Ministry of Foreign Affairs: https://www.mfa.gov.il/mfa/pressroo m/2010/pages/remarks_pm_netanyah u_us_president_obama_6-jul-2010.aspx Netanyahu, B. (2015, March 4). Transcript of Netanyahu Remarks to Congress. Retrieved November 05, 2019, from The New York Times: https://www.nytimes.com/2015/03/0 4/us/politics/transcript-ofnetanyahus-remarks-to-congress.html

Obama cited in The White House. (2010, May). National Security Strategy. Retrieved December 16, 2019, from Obama White House:

https://obamawhitehouse.archives.gov /sites/default/files/rss_viewer/nationa l_security_strategy.pdf

Obama cited in the White House. (2015, February). National Security Strategy. Retrieved December 16, 2019, from Obama White House: https://obamawhitehouse.archives.gov /sites/default/files/docs/2015_nationa l_security_strategy_2.pdf

Obama, B. (2010, July 6). Remarks by PM Netanyahu and US President Obama. Retrieved November 5, 2019, from Israel Ministry of Foreign Affairs: https://www.mfa.gov.il/mfa/pressroo m/2010/pages/remarks_pm_netanyah u_us_president_obama_6-jul-2010.aspx

Obama, B. (2012, 03 04). Remarks President Obama at AIPAC policy Conference. Retrieved November 05, 2019, from The White House President Obama : https://obamawhitehouse.archives.gov /the-pressoffice/2012/03/04/remarkspresident-aipac-policy-conference- 0

Office of the Director of National Intelligence. (2019, January 29). Statement for the Record: Worldwide Threat Assessment of the US Intelligence Community.

Retrieved September 30, 2019, from Office of the Director of National Intelligence: https://www.dni.gov/files/ODNI/docu ments/2019-ATA-SFR---SSCI.pdf
Olmet, O. (2006, May 24). Address by PM Olmert to a Joint Meeting of the US Congress. Retrieved November 5, 2019, from Israel Ministry of Foreign Affairs: https://mfa.gov.il/MFA/Government/S peeches+by+Israeli+leaders/2006/Add ress+by+PM+Olmert+to+a+joint+meeti ng+of+US+Congress+24-May-2006.htm

Parsi, T. (2008). Treacherous Alliance: The Secret Dealings of Israel, Iran, and the United States pp.249. Connecticut: Yale University Press.

Pass, J. (2019). American Hegemony in the 21st Century: A Neo Neo-Gramscian Perspective (Routledge Advances in International Relations and Global Politics). London: Routledge.

Perkins, T. (2019, Febuary 19). Pro-Israel donors spent over $\$ 22 \mathrm{~m}$ on lobbying and contributions in 2018. Retrieved October 17, 2019, from The Guardian: https://www.theguardian.com/usnews/2019/feb/15/pro-israel-donorsspent-over-22m-on-lobbying-andcontributions-in-2018

Pieper, M. (2017). Hegemony and Resistance Around the Iranian Nuclear Programme: Analysing Chinese, Russian and Turkish Foreign Policies. Chicago: Taylor \& Francis.

Plesch, D. D., \& Buthcer, M. (2007). Considering a war with Iran: A discussion paper on WMD in the Middle East. London: SOAS.

Pollack, K. (2014). The Persian Puzzle: The Conflict Between Iran and America. New York: Random House.

Riedel, B. O. (2016). The Clinton Administration. Retrieved October 28, 2019, from The Iran Primer: https://iranprimer.usip.org/resource/c linton-administration

Ripsman, N., Taliaferro, J., \& Lobell, S. (2016). Neoclassical Realist Theory of International Politics. New York: Oxford University Press.

Robert Einhorn, R. N. (2019, March). Constraining Iran's Future Nuclear Capabilities. Retrieved September 30, 2019, from Brookings University: https://www.brookings.edu/wpcontent/uploads/2019/03/FP_201903 21_nuclear_capabilities_WEB.pdf

Rogers, P. (2005). The Second Bush Administration and US Policy Towards 
Iran. J. Humanities Vol. 12 (1): (55-66) , 55-64.

Rosati, J. A. (1995). A Cognitive Approach to the Study of Foreign Policy. Dalam L. Neack, J. A. Hey, \& P. J. Haney, Foreign Policy Analysis: Continuity and Change in Its Second Generation (hal. 49-70). New Jersey: Prentice Hall .

Rouhani Should Give Priority to Religious Freedom in Iran. (2013, September 18). Retrieved October 10, 2019, from US Commision on International Religious freedom:

https://www.uscirf.gov/reportsbriefs/perspectives/rouhani-shouldgive-priority-religious-freedom-in-iran

Shank, G. (2015). Anatomy of a Done Deal: The Fight over the Iran Nuclear Accord. Social Justice, Vol. 14 No.1, 1-18.

Shuel, R. (2006, March 7). AIPAC Conference Focuses on Hamas and Iran. Haaretz, hal. 301-303.

SIPRI. (2019, April 29). World military expenditure grows to $\$ 1.8$ trillion in 2018. Retrieved December 17, 2019, from https://www.sipri.org/media/pressrelease/2019/world-militaryexpenditure-grows-18-trillion-2018

Smith, D. (2019, May 7). The US Withdrawal from the Iran Deal: One Year on. Retrieved September 30, 2019, from Stockholm International Peace Research Institute: https://www.sipri.org/commentary/ex pert-comment/2019/us-withdrawaliran-deal-one-year

SSRS. (2017, October). Two-thirds of Americans want to stay in the deal. Retrieved October 17, 2019, from SSRS: http://i2.cdn.turner.com/cnn/2017/im ages/10/20/rel10e..iran,.north.korea.pdf

Steven Kull. (2007). Public Opinion in Iranand America on Key International Issues. Maryland: The Program on International Policy Attitudes.

The White House. (2017, December 18). A New National Security Strategy for a New Era. Retrieved December 16, 2019, from https://www.whitehouse.gov/articles/ new-national-security-strategy-newera/
The White House. (1994). A National Security Strategy of Engagement and Enlargement. Retrieved October 24, 2019, from Historial Office of the Secretary of Defense: https://history.defense.gov/HistoricalSources/National-Security-Strategy/

The White House. (2002). National Security Strategy. Retrieved October 28, 2019, from US Department of State Archive: https://2009-

2017.state.gov/documents/organizatio n/63562.pdf

The White House. (2006). National Security Strategy. Retrieved October 24, 2019, from Historical Office of the Secretary of Defense:

https://history.defense.gov/Portals/70 /Documents/nss/nss2006.pdf?ver=201 4-06-25-121325-543

The White House. (2010, May). National Security Strategy. Retrieved December 16, 2019, from Obama White House: https://obamawhitehouse.archives.gov /sites/default/files/rss_viewer/nationa l_security_strategy.pdf

The White House. (2015). The Historic Deal that Will Prevent Iran from Acquiring a Nuclear Weapon. Retrieved October 28, 2019, from The White House Barrack Obama: https://obamawhitehouse.archives.gov /issues/foreign-policy/iran-deal

The White House. (2016). The Iran Nuclear Deal: What You Need to Know about the JCPOA. Retrieved December 17, 2019, from Obama White House: https://obamawhitehouse.archives.gov /sites/default/files/docs/jcpoa_what_y ou_need_to_know.pdf

The White House. (2017). Donald J Trump Announces National Security Strategy advances American Interests. Retrieved November 27, 2019, from

https://www.whitehouse.gov/briefings -statements/president-donald-j-trumpannounces-national-security-strategyadvance-americas-interests /

The White House. (2017, October 13). Remarks by President Trump on Iran Strategy. Retrieved December 12, 2019, from https://www.whitehouse.gov/briefings -statements/remarks-president-trumpiran-strategy/ 
TThe White House. (2017). US National Security Strategy. Retrieved October 11, 2019, from The White House: https://www.whitehouse.gov/wpcontent/uploads/2017/12/NSS-Final12-18-2017-0905.pdf

The White House. (2018, May 8). President Donald J. Trump is Ending United States Participation in an Unacceptable Iran Deal. Retrieved December 16, 2019, from

https://www.whitehouse.gov/briefings -statements/president-donald-j-trumpending-united-states-participationunacceptable-iran-deal/

The White House. (2019). National Security Council. Retrieved December 16, 2019, from The White House: https://www.whitehouse.gov/nsc/

Tibon, A. (2018, May 9). U.S. Jews Torn Over Trump's Exit From Iran Nuclear Deal. Retrieved October 18, 2019, from Haaretz: U.S. Jews Torn Over Trump's Exit From Iran Nuclear Deal

Toosi, N. (2016, 04 10). J Street spots push back on GOP Iran deal advertising. Retrieved October 18, 2019, from Politico: https://www.politico.com/story/2016 $/ 10 /$ j-street-ad-iran-deal-229048

Truman cited in Bessette and Pitney. (2011). American Governmen and Politics: Deliberation, Democracy, and Citizenship. Massachusetts: Wadsworth Cengage Learning.

UN. (2015, July 15). Security Council, Adopting Resolution 2231 (2015), Endorses Joint Comprehensive Agreement on Iran's Nuclear Programme. Retrieved October 28, 2019, from UN News: https://www.un.org/press/en/2015/s c11974.doc.htm

UNSC. (2010, June 9). Security Council Imposes Additional Sanctions on Iran, Voting 12 in Favour to 2 Against, with 1

Abstention. Retrieved October 28, 2019, from United Nations:

https://www.un.org/press/en/2010/s c9948.doc.htm

UNSC. (2015, November 5). Resolution 2231 (2015) on Iran Nuclear Issue. Retrieved October 17, 2019, from UNSC: https://www.un.org/securitycouncil/c ontent/2231/background

US Congressional Research Service. (2018). Israel: Background and U.S. Relations. Congressional Research Service.

US Deparment of Treasury. (2019). Iran Sanctions . Retrieved November 5, 2019, from Resource Center: https://www.treasury.gov/resourcecenter/sanctions/programs/pages/ira n.aspx

US Department of State. (2019). Iran. Retrieved September 30, 2019, from US Department of State: https://www.state.gov/countriesareas/iran/

US Government Accountability Office. (2013, February). Report to the Chairman, Committee on Homeland Security and Governmental Affairs, US Senate. Retrieved October 28, 2019, from US Government Accountability Office: https://www.gao.gov/assets/660/652 314.pdf

Waltz, K. (1979). Theory of International Politics. California: Addison-Wesley Series.

Yerah, T. (1997). US, Iran in Secret Talks. Tel Aviv: Haaretz.

Zion, I. B., \& Winer, S. (2016, November 9). Netanyahu hails Donald Trump as a 'true friend' of Israel. Retrieved December 18, 2019, from Times of Israel: https://www.timesofisrael.com/netany ahu-hails-trump-as-a-true-friend-ofisrael/ 